\section{PUBLIC SECTOR VERSUS CIVIL SOCIETY: AN APPROACH TO AFFORDABLE HOUSING DEVELOPMENT IN THAILAND}

\section{Chaweewan Denpaiboon ${ }^{1}$ Vimolsiddhi Horayangkura ${ }^{2}$ Mitsuo Takada ${ }^{3}$}

\begin{abstract}
This article focuses on the identification and illustration of the shift in low income housing policy and implementation in Thailand. Housing is one of the major sectors of national development; it plays a vital role in a developing country. Policy and housing mechanisms have witnessed major shifts toward affordable housing since 1973, mainly implemented by the public sector. This article is concerned with the decentralization of the governmental role in providing shelters for low income groups to the present-day civil society activity in the creation of affordable housing. The role of civic social innovation in urban development was a result of key social structure changes to
\end{abstract}

\footnotetext{
${ }^{1}$ Assistant Professor, Department of Urban Environmental Planning and Development, Faculty of Architecture and Planning, Thammasat University

${ }^{2}$ Professor, Department of Urban Environmental Planning and Development, Faculty of Architecture and Planning, Thammasat University

${ }^{3}$ Professor, Housing and Environmental Design Division, Department of Architecture and Architectural Engineering, Graduate School of Engineering, Faculty of Engineering, Kyoto University
}

strengthen a community based on social capital. An affordable house is not a spatial organization but rather a reflection of social movement planning. The objectives of the study were (1) To analyze a comparative study between public sector and civic society approaches to affordable housing development by NHA and CODI; (2) To analyze the lesson learnt from development projects by government and civil society, using a thorough analysis of the process of participatory subsidies; (3) To identify the government policy and civic society by NHA and CODI effects on urban development processes in Bangkok Metropolitan Areas. This could help NHA to identify any necessary changes to policies to encourage low income housing development; and (4) To recommend a policy of affordable housing developments for the low income group. The research method comprised a field-base case study using observation, interviews, and questionnaires, which was conducted among a random selection sample of 200 households in Baan Eua Ah-torn Project and Baan Man Kong Project. These findings provide a policy framework that brings together three concepts. First, a policy of providing for low income groups alone is not effective in the development of housing projects; it should mix income groups for sustainable housing development. Second, Baan Man Kong Project places more emphasis on the process and continuity of development than Baan Eua Ah-torn projects. Third, both projects will support the housing shortage. In the final section, conclusions are drawn about social innovation in governmental policy, focusing on empowering experiments with decentralization and governmental democracy accessible to civil society and its interests. 


\section{Significance of the problems}

Currently, there are many problems that are bringing about a rapid increase in the shortage of low-income housing; the housing backlog is presently increasing at a rate of around 178,000 units per annum ${ }^{4}$ and there is insufficient housing provision for slum residents. Provision of lowincome housing is still inadequate by the public sector, which cannot meet the demand of the low income group. The national government policy through the National Housing Authority (NHA) has been responsible for providing low cost housing projects utilizing techniques of slum improvement schemes, sites and services schemes, land sharing schemes, slum relocation schemes, and housing construction in the form of flats, detached houses, and semi-detached houses (see Figure 1 and Figure 2). Public policy was designated to be responsible for operating the housing subsidy for the target groups of the less advantaged and low income earners throughout the country.

\footnotetext{
${ }^{4}$ During the period of 2003-2007, the government approved subsidies to low-income housing projects for infrastructure development cost such as the Baan Eua Ah-torn housing project at 80,000 Baht per unit, and Baan Man Kong-Project at 68,000 Baht per unit.

${ }^{5}$ Baan means houses or residential quarters, "Eua" means to be generous, to help, to assist , and "Ah-torn" means to care, to be concerned, kindness, thoughtfulness.
}

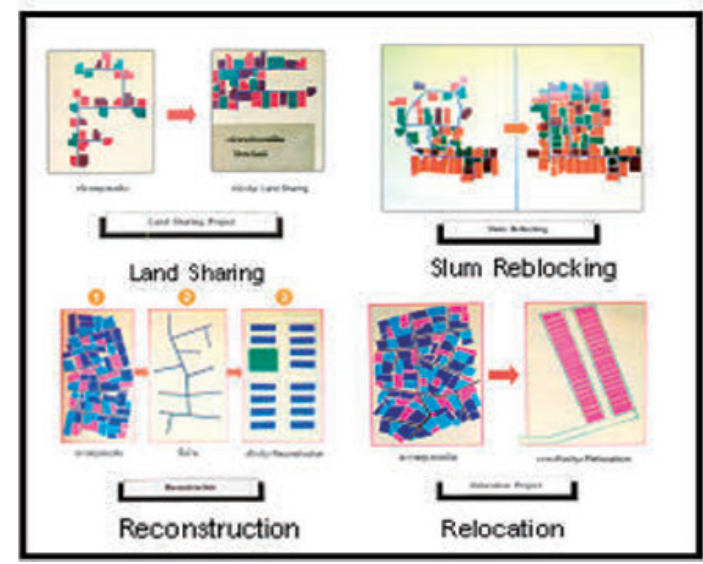

Figure 1: Type of housing development by NHA during 1980-2006

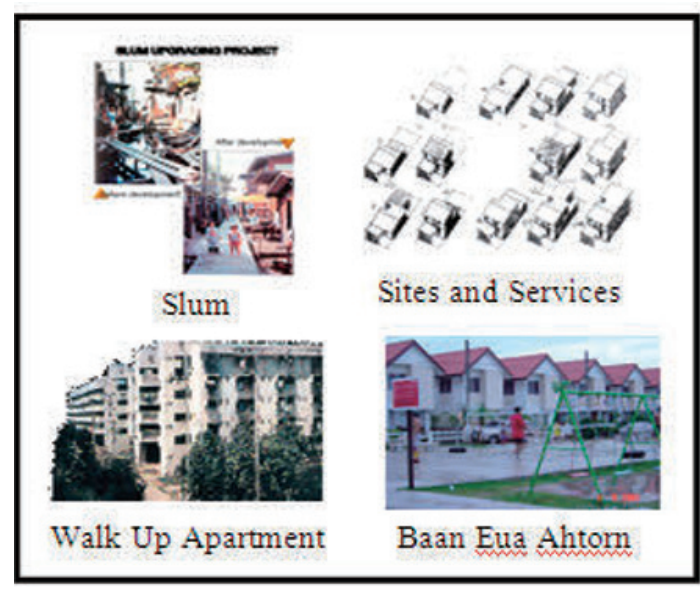

Figure 2: Type of housing development by NHA sector during1980-2006

This study aims to follow up and review the government policy in dealing with lowincome housing problems of the operating housing plan during 2003-2007, especially the utilization of Baan Eua-Ahtorn ${ }^{5}$ Project (BEA) and Baan Man Kong Project ${ }^{6}$ (BMK) as mechanisms for problem solving. The national policy, under the Ministry of Social Development and Human Security, was

\footnotetext{
${ }^{6}$ Baan means houses or residential quarters, "Mankong" means to be strengthen.
} 
entrusted with resolving the housing problem the less advantaged, low-income earners, junior civil servants and public agencies' personnel, so that they could afford their own residential quarters. NHA was to construct a total number of 601,727 units in 5 years from 2003 to 2007. NHA sought for the business alliances to implement the "Baan Eua Ah-torn Project" (BEA) for low income earners to hire-purchase residential units, with pre-determined essential furniture. The Community Organization Development Institute (Public Organization) or CODI played a leading role in supporting the "Baan Man Kong Project" (BMK). The national government assigned CODI to develop 300,000 housing units within 5 years from 2003 to 2007. Housing subsidy policy for Low-income housing projects, is a subsidy from the government to make the project affordable for the low-income target group. Almost always, that subsidy goes into building and infrastructure. BEA program is subsidized by the government, and works out to just 80,000 Baht (US\$ $1,777)$ per unit. The BMK program is be subsidized for an infrastructure subsidy of 40,000 Baht (US\$ 889) per unit and reconstruction subsidy at 28,000 Baht (US\$ 622) per unit.

The concept of development of affordable housing has 2 methods. First, supplydriven quantitative production by NHA of 20,000 units per year is operated for disadvantaged people and low-income earners in urban areas who have never owned housing, including low level civil servants and state enterprise employees with a household salary level less than 15,000 Baht per month (As of 2003). Second, Demand-driven or people-driven supply is operated by CODI as a process designed and managed the poor urban citizens for their community organization and networks. Community networks work with local governments, professionals, universities, and NGOs in their city to survey socioeconomically disadvantaged sectors in order to develop an improvement condition plan. (see Figure 3)

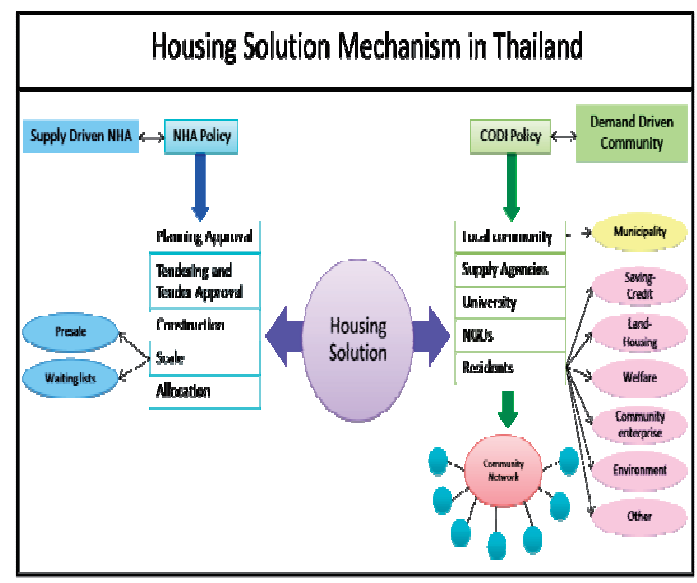

Figure 3: Housing solution mechanism in Thailand

During the late 1980s and early 1990s, the focus on NGOs began to shift, with an increasing emphasis being placed on the term "civil society" rather than "public sector." Friedman (1992) frames this shift via empowerment of people criteria, referencing three aspects as follows: (1) social power concerns household products, (2) political power concentrates on accessibility of people's decision-making, and (3) psychological power explores the individual empowerment reinforced in order to achieve social and political space.

The new paradigm of low-income housing development in Thailand has shifted from the "service providers" of the public sector to the "target groups", or "the people", as the principal "owners and actors" according to Paiboon (2003). Moreover, Putnam (1993) argues that the public sector is in disrepute and civil society is 
often proposed as an alternative; the crisis of policy-making has spurred reflection on the role of social actors in the conception and execution of public policy.

\section{Research objectives and methodology}

The objectives of this paper are as follows;

1. To analyze a comparative study between public sector and civic society approaches to affordable housing development by NHA and CODI;

2. To analyze the lessons learnt from development projects by public sector and civil society, using a thorough analysis of the process of participatory subsidies;

3. To identify the government policy and civic society by NHA and CODI effects on urban development processes in Bangkok Metropolitan Areas. This could help NHA to identify any needed changes to policies to encourage low income housing development.

The research method used in this study had two aspects: quantitative study consisting of a survey research and qualitative study. Data analysis employed the technique of socio-economic analysis and community development index using human index of $\mathrm{UNDP}^{7}$. We are applying a formula

\footnotetext{
${ }^{7}$ Human Development Index (HDI) is a composite statistic used to measure levels of "Human Development" (high, moderate, and low development). The statistic is composed from dimension index 1-3 (as a indicator of standard of living collected at community level using the formula give in the methodology sector below). It is used to assess the impact of BEA and BMK project development on physical and social, economic development and social improvement.
}

defining the HDI promulgated by the United Nations Development Programme (UNDP) to analyze variable values. In general, to transform a raw variable, say Index, into a unit-free index between 0 and 1 (which allows different indices to be added together), the following formula is used:

Dimension indicator,

Indicator $\mathrm{X}=\underline{\text { actual value }- \text { minimum value }}$ maximum value - minimum value

In relation to the Major index, once the dimension indices have been calculated, determining the HDI is straightforward. It is a simple average of the three dimension indices, using the following formula:

$$
\begin{aligned}
\text { Dimension Index }= & 1 / \mathrm{N}\left(\mathrm{X}_{1}\right)+1 / \mathrm{N}\left(\mathrm{X}_{2}\right) \ldots \\
& +1 / \mathrm{N}\left(\mathrm{X}_{\mathrm{n}}\right) \\
\text { By, } \quad \mathrm{N}= & \begin{array}{l}
\text { Number of dimension } \\
\text { indicators }
\end{array}
\end{aligned}
$$

Baan Eua-Ahtorn (Rangsit Klong 3 Project) and Baan Man Kong (Klong Lum Noon Community Project), which were located fringe of greater Bangkok formed the focus of our case study (see Figure 4 and Figure 5). There were 200 samplings for household socio-economic surveys conducted in August 2006 and December 2007. The surveys aimed to investigate the socioeconomic structure of the community. It was also expected to assess certain effects of housing project developments on the people, such as affordable housing costs related to household income, job-to-housing balance, and effects on society in the change of the urban social structure to the new community 
development of two agencies. Descriptive statistics were also analyzed with the intention of exploring the different characteristics of the behavior of the poor and investigations among the participants of this survey. A questionnaire was the principel instrument for surveying. It consisted of questions about socio-economic information, participation in activities related to the community, and social relations in a strengthening community. This was in order to find out why the housing solution process had been developed by the government and by civic society, and how it had affected urban planning.

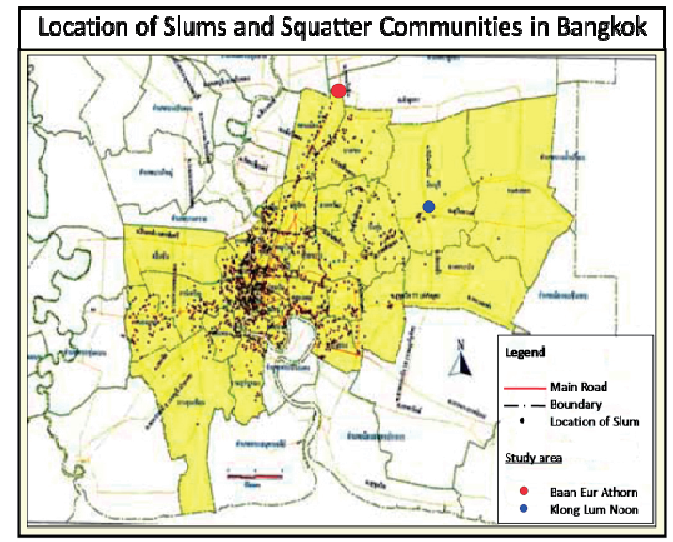

Figure 4: Location of study area (Chaweewan 2007)

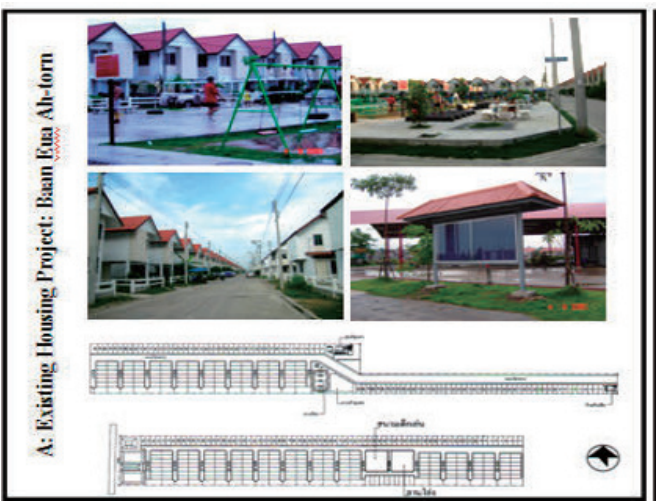

(A) Baan Eua Ah-torn

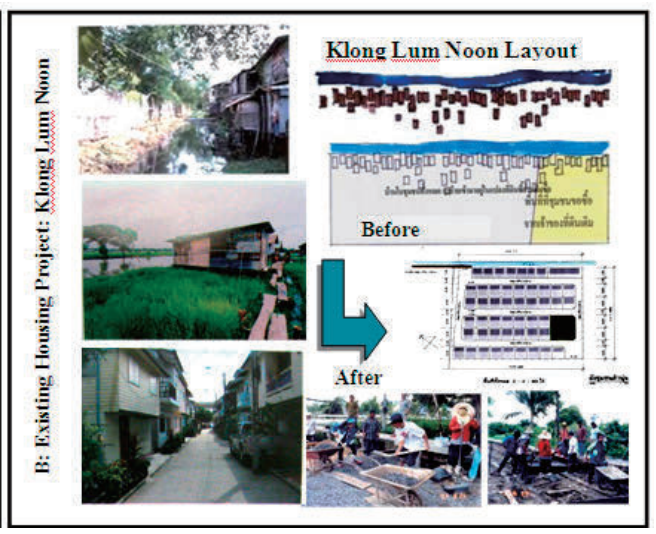

(B) Klong Lum Noon

Figure 5: Existing housing project

(Chaweewan 2007)

\section{Results and discussions}

The study highlights solutions for low income people and the poor which are implement by NHA and CODI, after projects have been allocated to the residents. The first was the result of the development of affordable housing for the target group of low-income people alone. The second concernings the impacts of project development on the urban and their living conditions.

The study was analyzed with six variables considered: benefits from living in the project, economic benefits of the project, benefits from project environment, social benefits of the project, and benefits from household quality. The study revealed that the residents benefit from low-cost housing development in terms of sound monthly repayments. The residents gained a sense of security when they moved to live in the project. The development can serve their basic needs of housing. Moreover, the residents were satisfied with the community design and living environment within the project. However, they were dissatisfied 
with the project location which is far from their work places. It requires more time for commuting and has impacted their lifestyles.

As a public developer, NHA carried out the BEA project mainly to serve the housing needs of low-income people. Project layout and design was simply made. It was found that the project density is sub-standard. However, the residents can accept that an extension of the house may negatively affect the living environment of their community. This concept corresponds with the housing study, which identified that low-income people are concerned with the housing price rather than the good living environment. In contrast, the BMK project has supported the slum's residents based on mutual support. The participatory community design process on Baan Man Kong was as follows: families were divided into 2-3 groups and into subgroups of 15 households, which would link together in a new project. The sub group was the basic group for linking members together, planning, saving collection, and dealing with welfare. Most houses were built by contractors: hired by the community, with some community labor contribution. Besides housing project activities of construction, material purchase, and account project supervising, the community set up task forces to oversee a lot of other community activities such as environment, income generation, education, cultural welfare, youth groups, elderly groups, and community micro-finance.

During analysis of the economic benefits of the project, it was found that the BEA project development still couldn't serve the basic economic needs of the community. The residents had no opportunity for generating income through running their own businesses. Due to lack of vendors, many food stalls had to close. The projects to promote special occupation in the community are still abstract. This phenomenon was also present in the BMK project.

\section{Impact of BEA project development on living conditions}

Five variables, including repayment, security, project layout, satisfaction with way of life, and increased house values were used to evaluate the impact of project development on living conditions of the people around the project. Level of opinion towards the BEA project development scored from highest to lowest: five for "strongly agree", four for "agree", three for "neutral", two for "disagree", and one for "strongly disagree." The study indicated that the repayment rate was reasonable and affordable. It was accounted for in seventy-nine percent of the sample, while sixty percent of the sample agreed that they had greater residential security after moving into the project. Fifty-nine percent agreed that the project has a good community layout and living environment. Sixty-three percent were satisfied with the existing way of life. Thirty-nine percent thought that the value of their houses had increased. However, it was found that the low-income people could access the lowcost housing market only at the basic needs level.

\section{Impact of BEA project development on physical and social conditions of the community}

There were 4 variables for finding out the impact of project development on physical and social conditions of the beneficiaries in the project. Those 4 variables were the changing ways of life caused by time for 
travel, the livability of community, the changing physical conditions of the community caused by extensions to the house structures, and the sense of pride for taking part in community development. Level of opinion towards the project development was scored from highest to lowest: five for "strongly agree", four for "agree", three for "neutral", two for "disagree", and one for "strongly disagree". The study revealed that forty-eight percent of the sample agreed that they spent more time for travel. Sixty-six percent agreed that they have better living environments, while forty-seven percent agreed they had good neighbors. Those, who thought they had a sense of pride, accounted for nearly sixtyone percent. (See Figure 6)

\section{Impact of BEA project development on economic development}

The following were variables for evaluating the economic development impact of the project. The study focuses on the interest of residents in having a market fair in the community; residents' satisfaction with the existing community businesses; residents' needs for promotion of extra income; job training; the needs of attractive business promotion; and the economic enhancement of running a retail business. The results found that thirtyeight percent of the respondents agreed with the idea of having a market fair in the community.

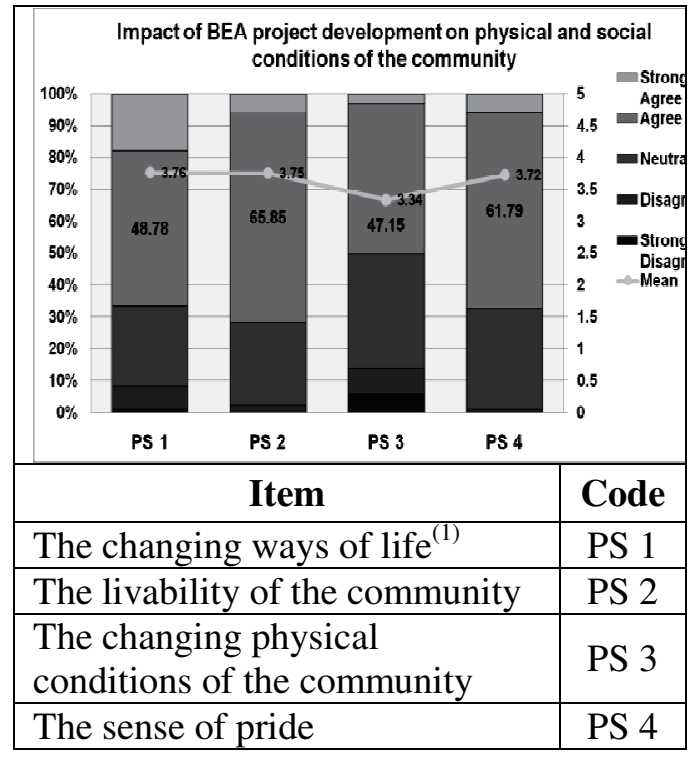

Remark: (1) Converting value

Figure 6: Impact of BEA project development on physical and social conditions of the community

Fifty-four percent of the total was satisfied with existing retail shops in the community, while fifty-nine percent of those surveyed agreed that they needed to increase income, and fifty-two percent required job training. Forty-eight percent agreed that the businesses in the community could also provide services for outsiders. More than half (fifty-five percent) of the respondents felt that the businesses in the community had enhanced the economic development of the community. (See Figure 7) 


\begin{tabular}{|l|l|l|l|}
\hline \multicolumn{3}{|c|}{ Impact of BEA project development on economic } \\
development
\end{tabular}

Figure 7: Impact of BEA project development on economic development

\section{Impact of project development on social improvement}

The study used 9 variables to identify whether the project development had any impact on social improvement. These variables included 1) activity group setting, 2) unity creation, 3) community leadership, 4) organization of meeting to promote the community unity, 5) setting of rules and regulations to enhance community unity and harmony, 6) networking among communities, 7) activity performance, 8) election of a community committee, and 9) public participation of community members in development of the surroundings. The study indicated that sixty-four percent of the respondents agreed to have an activity group set. More than half of the total fiftythree percent agreed that their community is harmonious. Those who considered having a community leader to be significant accounted for fifty-nine percent. Fifty-four percent required rules and regulations to help community unity. More than half of the total (fifty-five percent) wanted networking among the community. Around forty-one percent agreed that the community leader should come from their community, not from the government sector, while fifty-nine percent preferred doing activities within their neighborhoods. Fifty-nine percent agreed that the community had impacted the development of the community surroundings. Forty-one percent considered that for electing a community leader was significant. Sixtytwo percent expected to have public participation. (see Figure 8)

\section{Impact of BMK community on urban development by community based development after the completion of project allocations.}

The study indicates that the "BMK Community"; Klong Lumnoon Community is a possible continuity of the community is development. Hence, the study has followed up issues concerning the group leader, the group of residents related with community development, and risk factors affecting the community. There were 11 variables for determining risk factor effects on community development as follows: decreasing relationships, lack of of volunteers, lack discipline in finance dependent leadership, bad attitude toward other residents, decreasing participation, lack of young people, lack of success in solving problems by oneself, ignorance of 
community development, overloading the job of leader, and satisfaction in basic needs.

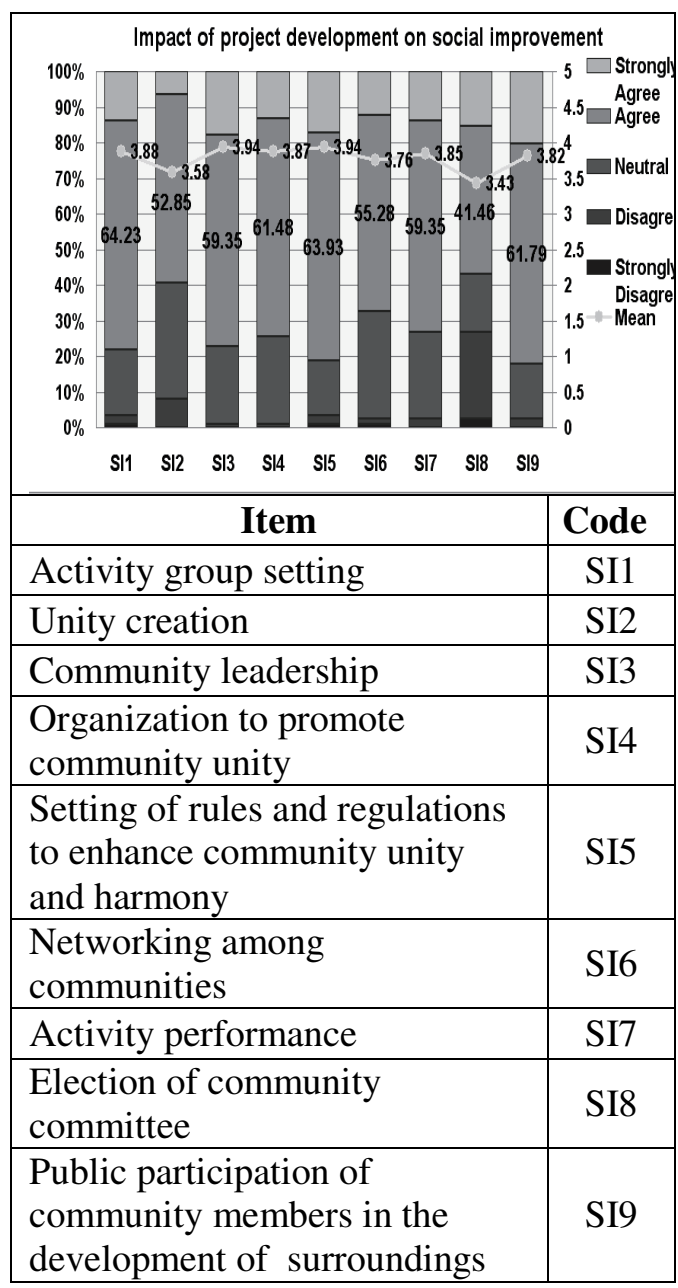

Figure 8: Impact of project development on social improvement
The group leader points out that residents in the community might meet high risks in terms of undisciplined finance, decreasing participation, and lack of solving problems by oneself. The group of residents point out the same factors of high risk of decreasing participation and a, lack of disciplined finance among the young generation (see Figure 9, Figure 10, and Figure 11).

For community development, the study shows that the residents' first priorities are poverty reduction, community strengthening, and community itself, respectively. While group leaders priorities were poverty reduction, community strengthening, and community management, respectively (see Figure 11). 


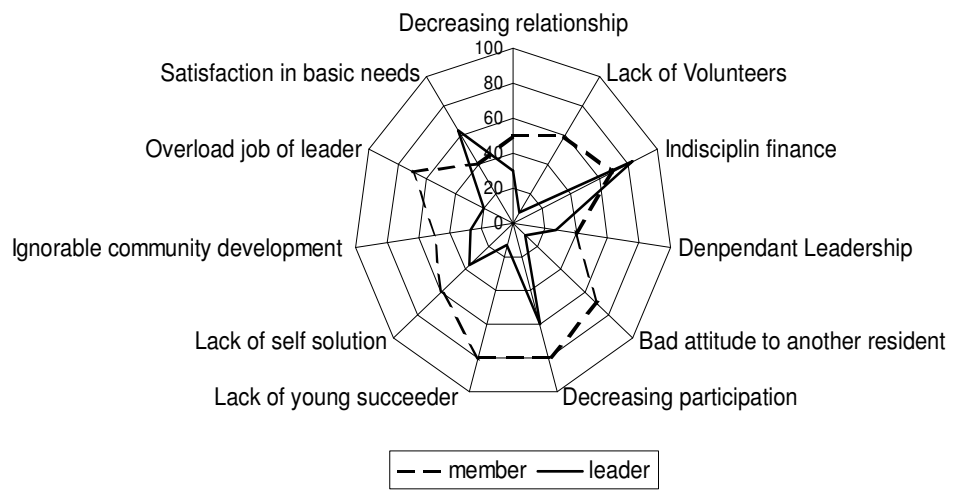

Figure 9: Risk Factor Effect to community

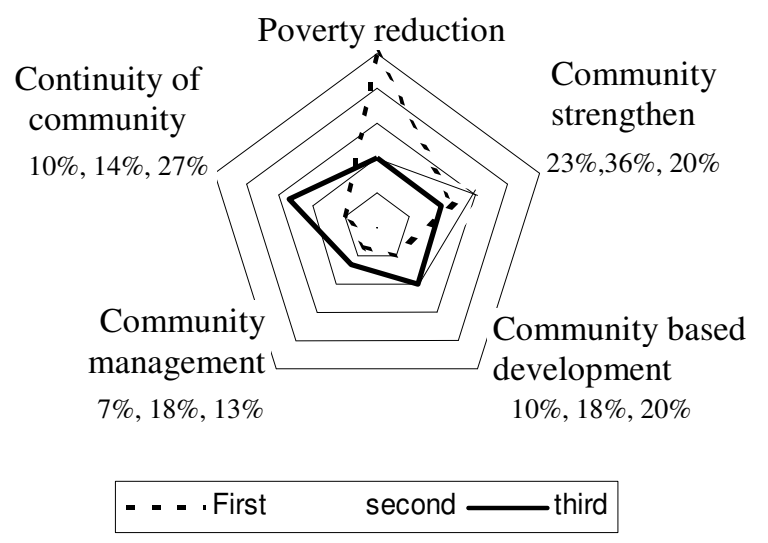

Figure 10: Goal of Member in Community development

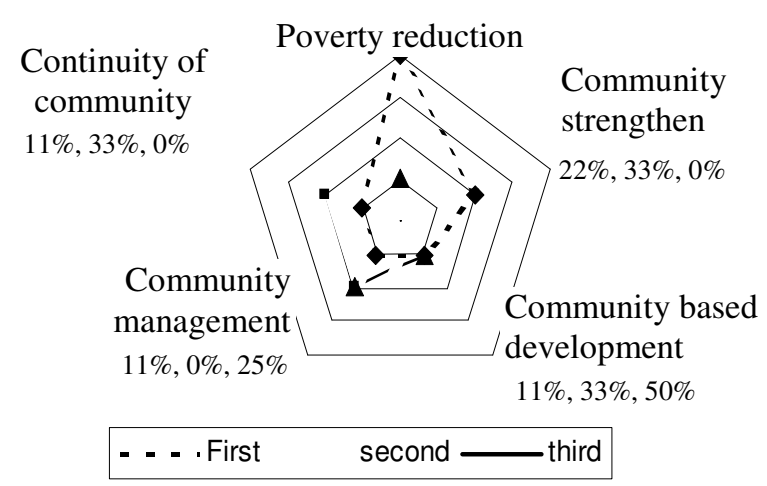

Figure 11: Goal of Leaders in community development 
During analysis of the economic benefits of the project, the study found that the resident's own food shop couldn't serve the basic economic needs of the community. The residents had no opportunity to generate income through the running of their own businesses, and vendors or many food stalls had to close. ${ }^{8}$ Projects to promote special occupation in the community are still being obstructed. This phenomenon was also found in the BMK community.

The following human development index was developed by the United Nations Development Programmes (UNDP). HDI model is grouped in in a new category called very high human development, which combines six factors as detailed below. Table1 and Figure12 illustrate economic development indicators and index between BEA and BMK development project, it reveals that the dimension of economic development indicator of BMK development project is higher than BEA development project. In addition, the dimensions of economic development index of BMK development are also higher than in the BEA development project.

\footnotetext{
${ }^{8}$ This is based on the author's survey in 2006.
}

Table 1: Economic development index between BMK and BEA development project

\begin{tabular}{|c|c|c|c|c|c|}
\hline \multirow[b]{2}{*}{ Items } & \multirow{2}{*}{ Code } & \multicolumn{2}{|c|}{ BEA } & \multicolumn{2}{|c|}{ BMK } \\
\hline & & D1 & D2 & D1 & D2 \\
\hline $\begin{array}{l}\text { The interest of residents } \\
\text { in having a market fair } \\
\text { in the community. }\end{array}$ & ED1 & 0.58 & & 0.63 & \\
\hline $\begin{array}{l}\text { The residents' } \\
\text { satisfaction with } \\
\text { existing community } \\
\text { business. }\end{array}$ & $\mathrm{ED} 2$ & 0.72 & & 0.75 & \\
\hline $\begin{array}{l}\text { The residents need for } \\
\text { promotion of extra } \\
\text { income }\end{array}$ & ED3 & 0.65 & 65 & 0.66 & 0.68 \\
\hline Job training & ED4 & 0.66 & & 0.72 & \\
\hline $\begin{array}{l}\text { Need for business } \\
\text { promotion. }\end{array}$ & ED5 & 0.63 & & 0.63 & \\
\hline $\begin{array}{l}\text { The economic } \\
\text { enhancement of running } \\
\text { a retail business. }\end{array}$ & ED6 & 0.65 & & 0.7 & \\
\hline
\end{tabular}

Remark: D1: Dimension Indicators D2: Dimension Index

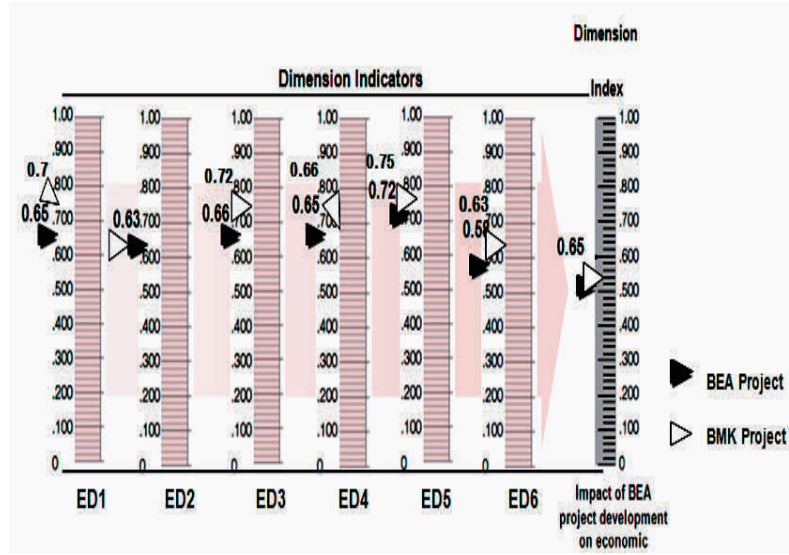

Figure 12: Economic development index between BMK and BEA development project

Aspects of social fabric development: Development of the "BEA community" and the "BMK community" was implemented and showed success mainly in terms of physical-environmental development. Other than this, it is apparent that urban-level social fabric 
development was not found in the community development project, that residents of the BEA community had no coherence amongst those groups and that they suffered from and faced many problems of living in the community. At the same time, it was found that the "BMK community" Klong Lum Noon Community is still losing strength followings its successes in critical slum eviction. In spite of the community possessing social capital, in terms of empowering people and enhancing their ability to tackle problems, as well as increased knowledge of actual urban development processes, social development problems still remain. Therefore, it is recommended that social development should not be disregarded. In other words, social development should be continued in order to make the community strong .

Aspects of the target group of low income earner development alone: Both communities have a lack of economic building projects to promote income generation for families. As a vulnerable group, they are willing to make food and do everything by themselves. However, project implementation for the low income group was easy-todesign housing projects development. Accessibility and affordability of housing is not considered as a goal achievement, regardless of the significance of community environment improvement and community strengthening.

Table 2 and Figure13 show the comparison of social condition dimension indicator and social condition dimension index between the BEK development project and BMK development project; it reveals that BMK development project receives outcomes higher than the BEA development project in social condition indicators and social condition index respectively.
Table 2: Physical and social development index between BMK and BEA development project

\begin{tabular}{|c|c|c|c|c|c|}
\hline \multirow{2}{*}{ Items } & \multirow{2}{*}{ Code } & \multicolumn{2}{|c|}{ BEA } & \multicolumn{2}{|c|}{ BMK } \\
\hline & & D1 & D2 & D1 & D2 \\
\hline $\begin{array}{l}\text { The changing ways of } \\
\text { life }^{(1)}\end{array}$ & $\begin{array}{c}\mathrm{PS} \\
1\end{array}$ & 0.31 & & 0.7 & \\
\hline $\begin{array}{l}\text { The livability of the } \\
\text { community }\end{array}$ & $\begin{array}{c}\text { PS } \\
2\end{array}$ & 0.58 & & 0.6 & \\
\hline $\begin{array}{l}\text { The changing physical } \\
\text { conditions of the } \\
\text { community }\end{array}$ & $\begin{array}{c}\text { PS } \\
3\end{array}$ & 0.59 & 0.51 & 0.49 & 0.61 \\
\hline The sense of pride & $\begin{array}{c}\text { PS } \\
4 \\
\end{array}$ & 0.57 & & 0.63 & \\
\hline
\end{tabular}

Remark: (1) Converting value D1: Dimension Indicators D2: Dimension Index

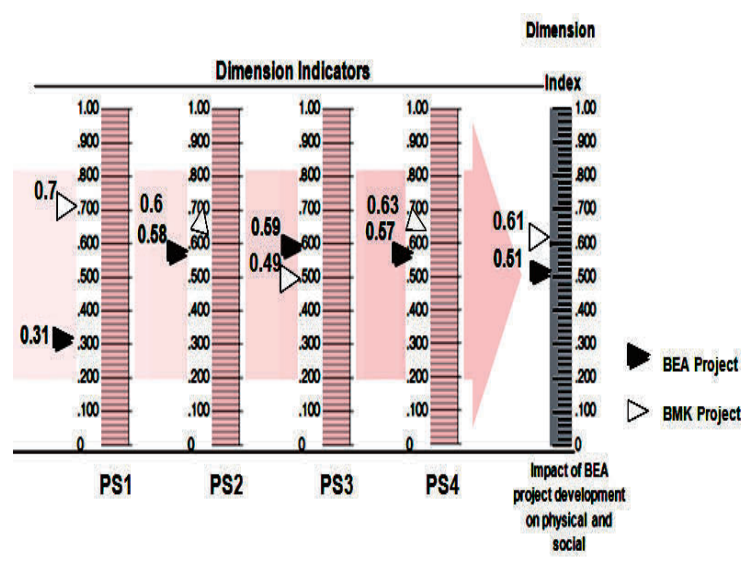

Figure 13: Physical and social development index between BMK and BEA development project

Aspect of process for development of the "BEA community" and the "BMK community": considering the housing project development of the BEA community, NHA designs the plan and layout of the project, while buildings are co-structed by contractors. This shows the public sector is concerned primarily with the affordability of low-income earners. Moreover, the completed projects become an intervention into the urban fabric of the old project. Such an intervention is 
considered as development process that causes an increase of community density. The project can provide inhabitants with significant community facilities and utilities, including sports facilities, playgrounds, multi-purpose buildings, and common areas. Nevertheless, the residents find it difficult to access community facilities. ${ }^{9}$ Compared with the BMK Project, the development process was formed by a community-based approach; the inhabitants design and build the community themselves. It could be said that the civic society was involved in every step of the urban planning process. This process can help in empowering the people.

Table 3 and Figure 14 illustrate the comparison of social improvement indicators and social improvement index between the BEK development project and the BMK development project. It reveals that the BMK development project is higher than the BEA development project in social improvement indicators and social improvement index respectively.

Aspects of support for civil society; It is worth distinguishing between two different kinds of civil society organizations that are active in environmental issues.

\footnotetext{
${ }^{9}$ This is based on the author's survey in 2006.
}

Table 3 Social improvement index between BMK and BEA project development

\begin{tabular}{|c|c|c|c|c|c|}
\hline \multirow[t]{2}{*}{ Item } & \multirow[t]{2}{*}{ Code } & \multicolumn{2}{|c|}{ BEA } & \multicolumn{2}{|c|}{$\begin{array}{c}\mathbf{B M} \\
\mathbf{K}\end{array}$} \\
\hline & & D1 & D2 & D1 & D2 \\
\hline Activity group setting & DS1 & 0.72 & & 0.75 & \\
\hline Unity creation & DS2 & 0.53 & & 0.72 & \\
\hline Community readership & DS3 & 0.65 & & 0.69 & \\
\hline $\begin{array}{l}\text { Meeting to promote } \\
\text { community unity }\end{array}$ & DS4 & 0.62 & & 0.74 & \\
\hline $\begin{array}{l}\text { Setting of rules and } \\
\text { regulations to } \\
\text { enhance community } \\
\text { unity and harmony }\end{array}$ & DS5 & 0.74 & & 0.77 & 0.72 \\
\hline $\begin{array}{l}\text { Networking among } \\
\text { communities }\end{array}$ & DS6 & 0.69 & & 0.77 & \\
\hline Activity performance & DS7 & 0.62 & & 0.71 & \\
\hline $\begin{array}{l}\text { Election of community } \\
\text { committee }\end{array}$ & DS8 & 0.61 & & 0.65 & \\
\hline $\begin{array}{l}\text { Public participation of } \\
\text { community member in } \\
\text { development of the } \\
\text { surrounding }\end{array}$ & DS9 & 0.61 & & 0.68 & \\
\hline
\end{tabular}

Remark: D1: Dimension Indicators D2: Dimension Index

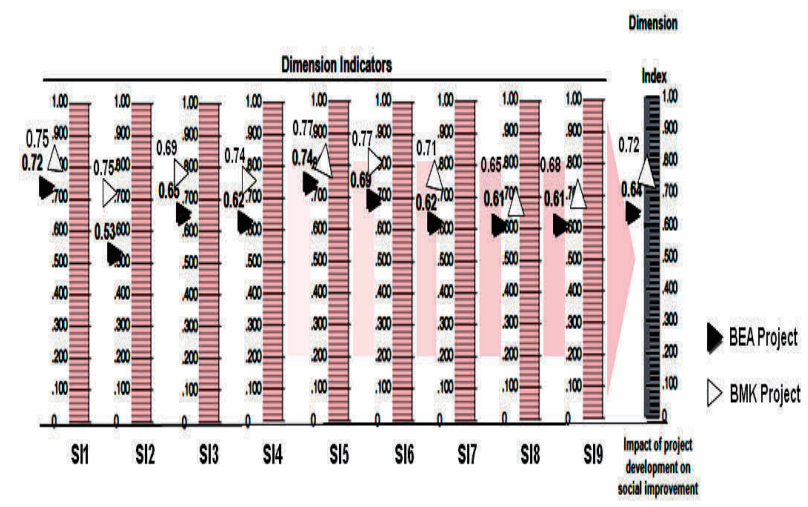

Figure 14: Social improvement index between BMK and BEA project development

The first is one whose primary purpose is to work at the grassroots level to improve the environment - for instance, community organizations formed by the 
residents of low-income neighborhoods and the local NGOs that work with them. The second is one that concentrates on documenting environmental problems and using this as the basis for demanding action - for instance, documenting the 'state of the environment' in a city or highlighting the extent to which air pollution standards are being violated and who the main contributors are.

\section{Conclusion}

The study reviewed here clearly establishes potential issues with standard government policy for affordable housing in sustainable development; in particular, the policy focuses on a target group of low income earners alone. Through a comparative study of the 'BEAcommunity' and 'BMK-community', the study found that it is difficult to achieve optimal success with a redevelopment project, especially in terms of promoting a desirable residential environment. The empirical evidence for-specific income groups against these performance criteria is weak or variable. A study of mixedincome groups in housing development projects in the USA by Brophy (1997) and Murphy found general satisfaction among residents. Aspects of achieving objectives;

The study shows the impact of nonprofit housing development has been framed by NHA and CODI in terms of benefits to low income households and community.

They concluded that having different income groups living together comfortably was a 'significant accomplishment' in a society increasingly segregated by income. But there were specific problems (such as, at a micro level, working class or 'underclass' teenagers terrorizing middle- class neighbors). Moreover, mixing incomes in an estate does not necessarily mean that unemployed people are more likely to find work. Key factors which contribute to effective programs demonstrate what is important to address in the 'BEA-community' and 'BMKcommunity' - society-wide social and economic forces which impact upon mixed groups in housing development projects and make it difficult for some of them to avoid the risk factors which lead to unemployment or to destructive or antisocial behaviors and society-wide social.

\section{Acknowledgements}

The paper reports part of the finding of the project entitled "Affordable Housing Development Impact for Low-Income Group on Urban Development: A Case Study of Baan Eua Ah-torn" Project, Rangsit Klong 3, Thailand studied in (2007). The study was carried out with a grant provided by the Thailand Research Fund. Thanks are also due to the Faculty of Architecture and Planning, Thammasat University for kind assistance in the conduct of the study.

\section{References}

Brophy, Paul C. and Rhonda N. Smith. 1997. Mixed-Income Housing: Factors For Success. Cityscape 3.2: 3-31.

Chaweewan Denpaiboon. 2007. Impact of Affordable Housing on Urban Planning: A Case Study of Baan Eua Ah-torn: Rangsit Klong 3. Thammasat University. Thailand.

Friedman, John. 1992. Empowerment: The Politics of Alternative Development. Oxford: Blackwell. 
Paiboon Wattanasiritham. 2003. The Resource Alliance. in collaboration with the "Development Support Consortium" Paper presented at the 4th International Workshop on Resource Mobilisation (5 8/05/2003), Bangkok. Thailand, Thai Fund Foundation.

Putnam R.D. 1993. Making Democracy Work: Civil Tradition in Modern Italy. Princeton, NJ: Princeton University Press.

---. UNCHS. 1991. (Habitat) Nairobi. Developing a national shelter strategy: Lessons from four countries. 